\title{
The Ability of Human Resources in Compiling Financial Reports at the Ministry of Religion Office of Sabang City
}

\author{
Eddi Fahmi $^{1}$, Ismail ${ }^{2}$, T. Syarifuddin ${ }^{3}$ \\ 1,2,3 Universitas Iskandarmuda, Indonesia \\ ismail.unida@gmail.com
}

\begin{abstract}
Enhancement ability human resources of service officers at The Ministry of Religion Office of Sabang City has so far been carried out in two ways, namely through education and training. Then also carried out an increase in ASN discipline in the preparation of financial reports so that employees doing their duties in a timely manner, with the right quality and comply with applicable regulations. The purpose of this research are to find out and analyze the improvement of ASN's ability in compiling financial reports at the Ministry of Religion Office of Sabang City and to find out and analyze the improvement of ASN discipline in the compiling financial reports at the Ministry of Religion Office of Sabang City. Researchers used qualitative methods in order to collect data with the technique of determining the informants was done by purposive sampling. The results showed that ASN ability still low, especially with regard to the level of education and training. Then civil servant discipline at the Ministry of Religion Office of Sabang City is still low, especially regarding getting to the office on time, this is still often not appropriate, as well as with the right quality because it is not on time then automatically it is not of the right quality, but employees obey the applicable rules. The conclusion of the study shows that Education is an important factor in improving human resources at the Ministry of Religion Office of Sabang City, but higher education is not a guarantee for someone to be placed in a structural position by the head. Then related to the training attended by the employees of the Ministry of Religion of Sabang City, they participated in various trainings and usually one training lasted for four days. Employees at the Ministry of Religion Office of Sabang City are still not disciplined in their work because they enter the office not on time, and return home not on time so that the results are not of the right quality but other rules are obeyed and obeyed. In terms of responsibility, they are still low, but they have a good attitude at work.
\end{abstract}

Keywords

Ability; human resource; financial reports

\section{Introduction}

Human resource development can be done in various ways, including through training, workshops and educators. Thus, institutional leaders should facilitate and develop the potential of employees or staff in their institutions in accordance with institutional demands so that they are able to develop and be able to work optimally based on Standard Operating Procedures (SOP). Qualified employees will certainly be a mainstay for the realization of the goals desired by an organization. In this case, personnel capacity building needs to be carried out both formally and non-formally through the development of human 
resources based on the work program of religious institutions can perform the service function in an excellent manner.

Human resource development is one of the important aspects in an effort to increase organizational excellence. Given that Human Resources (HR) is one of the important factors in an organization, therefore management is needed or commonly known as human resource management. According to Hasibuan (2016) human resource management has various functions including "planning, development, integration, maintenance, discipline, and termination". All functions of human resource management aim to increase the role and contribution of human resources owned by the organization so that organizational goals can be achieved effectively and efficiently.

Improving the ability of service officers carried out by The Ministry of Religion Office of Sabang City so far has been through two ways, namely through education by supporting every employee who continues their education as well as through various trainings carried out both internally by the Ministry of Religion of Sabang City and externally organized by outside institutions. Then also carried out an increase in ASN discipline in the preparation of financial reports at the Ministry of Religion Office of Sabang City so that employees can carry out their duties in a timely manner, with the right quality and comply with applicable regulations. However, the problem with the various efforts made by the Office of Ministry of Religion of Sabang City relates to the form of discipline that is still lacking, especially with regard to attendance and responsibility, while the attitude is adequate, so that it affects the services provided.

Based on initial observations at the research location, it shows that there are various efforts to increase the capacity of human resources, especially in terms of preparing financial reports, changing services towards a better direction by the Ministry of Religion. Sabang City concerning general guidelines for the administration of administrative services, such as timely service, appropriate quality service requirements, the ability of service personnel, as well as responsibilities in providing services.

In this case, Ministry of Religion Office of Sabang City have consequences for increasing ability human resources in order to contribute to improving the ability to prepare financial reports. Ministry of Religion Office of Sabang City is part of an organization that has a commitment to have a sense of belonging for employees towards the organization. If employees feel that their soul is tied to the existing organizational values, they will feel happy at work, so that organizational performance can increase. The phenomenon related to the increase in Human Resources (HR) at the Ministry of Religion Office of Sabang City, has given a new color to government institutions to further improve their capabilities, especially in terms of compiling financial reports.

\section{Review of Literature}

\subsection{Human Resource Theory}

Human resources are people in the organization who contribute ideas and do various types of work in achieving organizational goals. The contribution in question is in the form of thoughts and work they do in various activities within the institution or organization. In terms of human resources, what is covered is not limited to experts, educational staff or experienced personnel, but all workers used to realize its goals. The word resource according to Achmad (2016) explains that "From an etymological point of view the word source is given the original meaning while the word power means strength or ability. Thus resource means ability or origin of strength. While Susilo (2018) said that: 
Resources are defined as tools to achieve goals or the ability to take advantage of certain opportunities, or escape from difficulties so that the word resource does not indicate an object, but can play a role in a process or to achieve certain goals such as fulfilling satisfaction. In other words, human resources is an abstraction that reflects human aspirations and relates to a function or operation.

In order to carry out various activities, every organization or government institution must have strong resources. The resources needed by an institution or organization cannot be seen as an independent part, but as a formidable unit forming a synergy. According to Philip (2018) Human resources are a translation of "Human resources, but there are also those who equate human resources with manpower (labor). Some people equate the notion of human resources with personal (personnel, staffing, and so on).

Human resources are the only resources that have feelings, desires, skills, knowledge, encouragement, power, and work (ratio, taste, and intention). All potential human resources affect the organization's efforts to achieve goals. No matter how advanced technology, the development of information, the availability of capital and adequate materials, without human resources it is difficult for the organization to achieve its goals. Dewi (2016) states that human resources are "Employees who are ready, capable, and alert in achieving organizational goals". The main dimension of the human resource side is its contribution to the organization while the main dimension of human is the treatment of its contribution which in turn will determine the quality and capability of life. High-quality human resources according to Anwar (2016) are "Human resources who are able to create not only comparative value but also competitive-generative-innovative value by using the highest energy and no longer solely using crude energy such as raw materials, land, water, muscle power, and so on. Human resources must be interpreted as a source of strength from humans that can be utilized by the organization. Resources must be improved in quality and competence in order to become a strength. Human resources must be interpreted as a source of strength from humans that can be utilized by the organization. Resources must be improved in quality and competence in order to become a strength. Human resources must be interpreted as a source of strength from humans that can be utilized by the organization. Resources must be improved in quality and competence in order to become a strength.

To understand the meaning of Human Resources (HR) it is necessary to distinguish between: macro and micro meaning. The definition of human resources at a macro level according to Bambang (2017) is "All humans as residents or citizens of a country or within certain regional boundaries who have entered the age of the workforce, both those who have entered the age of the workforce, both those who have and have obtained work". Meanwhile, according to Edy (2016) Human Resources (HR) on a macro basis also means "People who are in productive age, although due to various causes and problems there are still those who are not productive because they have not entered the employment opportunities in their community".

Human Resources (HR) in the simple sense of micro according to Handok (2016) is "Humans or people who work or become members of an organization called personnel, employees, employees, workers, labor and others". Meanwhile, more specifically, HR in a micro sense according to Herman (2017) in an organization or company environment, the meaning can be seen from three angles:

1. HR is a person who works and functions as an organizational asset that can be counted in number.

2. HR is the potential that becomes the driving force of the organization. 
3. Humans are the resources of the creatures created by God Almighty, as the driving force of the organization. Its human values require that human resources be treated differently from other resources.

According to Jones (2016), human resources are "all the capabilities or potentials of the population residing in a certain area along with their demographic, social and economic characteristics or characteristics that can be utilized for development purposes". So discussing human resources means discussing the population with all its potential or abilities. Human potential involves two aspects, namely aspects of quantity and quality. Demographic characteristics are quantitative aspects of human resources that can be used to describe population size and growth, population distribution and population composition. Social and economic characteristics are related to the quality of human resources.

Human Resources (HR) is the most important component in a company or organization to run the business it does. Organization must have a goal to be achieved by the organizational members (Niati et al., 2021). Development is a change towards improvement. Changes towards improvement require the mobilization of all human resources and reason to realize what is aspired (Shah et al, 2020). The development of human resources is a process of changing the human resources who belong to an organization, from one situation to another, which is better to prepare a future responsibility in achieving organizational goals (Werdhiastutie et al, 2020).

\subsection{Organization Theory}

Organizations have very varied meanings, organizations can be seen as containers, processes, behaviors, and as tools to achieve goals. Siagian in Daryanto (2016) defines an organization as "a form of union between two or more people who work together for a common goal and are formally bound in an alliance, where there is a relationship between a person called the leader and a group of people called subordinates". While Henry in Daryanto (2016) organization is "a group of people who are formally bound to achieve goals".

Edgar in Daryanto (2016:) organization is "rational coordination of the activities of a number of people to achieve some clear goals through division of labor, functions, and through levels of authority and responsibility". According to Agung (2016) organization is "a pattern of relationships through which people under the direction of superiors pursue common goals and form every human association to achieve common goals as well as a system of cooperative activities carried out by two or more people". Meanwhile, according to Thoha (2016) states that organizational theory is "a theory that discusses human behavior starting from humans in tribal groups to humans in government". While the theory of administration is a theory that is based on human behavior in work groups which is widely used as the basis for the theory of state administration.

Bellon in Thoha (2016) states that "Organizational theory describes human behavior starting from the form of tribes to complex government, while administrative theory describes human behavior in work groups". In this era of globalization, we can see that there are various types of organizations that surround us, and even all of us are influenced by the existence of various organizations. And even data and facts can show that we live most of our daily lives with organizations, at least our lives are influenced by various organizational activities.

Organizations are formed by humans in order to achieve things that are impossible to do personally, that is the need for organizations, because organizations can help humans. To be able to carry out activities that are impossible to do both individually and this must 
be done together in order to be able to achieve a certain goal. If we explore further that Allah has created humans to live on this earth not alone, as individuals because they are in the dimension of the natural environment, then naturally they are in the community environment, and thus humans as individual creatures, because their existence must be able to position themselves as human beings. himself as a social being. And most importantly in maintaining his life on earth, humans need interaction with fellow humans. Therefore, humans in this life are very dependent on other humans.

Based on the above assumptions, it can be understood that organizations are social entities that are consciously coordinated and work together to achieve common or group goals. This is in line with the opinion of Robbins in Torang (2015) who says that the organization is "a consciously coordinated social entity, consisting of two or more people with relatively identifiable boundaries, which functions continuously to achieve a common set of goals". Furthermore, according to the opinions and views expressed by Davis in Torang (2015) categorizes that the organization is "a group of people who are working towards a common goal under leadership". Furthermore, Miller's view of organizations in Torang (2015) defines an organization as "People who work together, and thus contain the characteristics of human relationships that arise in group activities.

An organization must at least have, among other things, the presence of a number of people working together, the expected common goals, the interaction in carrying out the cooperation and the intended interaction to achieve common goals. For this reason, it is necessary to remember that each person in the organization individually has their own personal goals. And for the sake of personal personal goals that can be realized, the members of their organizations join the organization to work together in order to achieve common goals. Winardi (2016) explains and translates consciously coordinated words meaning management:

Social entity means that the unit consists of people or groups of people who interact with each other. The patterns of interaction that people in an organization follow do not just appear, they are considered beforehand. Considering that organizations are social entities, the interaction patterns of their members need to be balanced and harmonized in order to minimize conflicting activities. This is to ensure that critical tasks have been carried out. The result, then, is that the definition presented explicitly assumes there is a need to coordinate people's interaction patterns.

\subsection{Financial Theory}

Financial reports are a source of financial information for an organization regarding whether the financial position is in good condition or vice versa. The information in these financial reports can assist interested parties as a consideration in making decisions. The definition of financial reports according to the Indonesian Institute of Accountants in Financial Accounting Standards in Kasmir (2016) includes part of the financial reporting process, namely "Complete finances usually include balance sheets, income statements, statements of changes in equity, statements of changes in financial position (which can be presented in various ways). for example, as a cash flow statement/fund flow statement), notes and other reports and explanatory material that are an integral part of the financial reports".

According to Kasmir (2016) financial reports are "reports that show the current financial condition of the company or within a certain period". Meanwhile, according to Fahmi (2016) the definition of financial reports is "An information that describes the condition of a company's financial reports and furthermore this information can be used as a description of the company's financial performance". Financial reports generally include 
balance sheet, profit/loss statement, statement of changes in equity, cash flow statement and notes to financial statements. The financial report is a form of report that describes the financial condition of the company, the development of the company and the results of operations of a company in a certain period of time.

The main purpose of making and preparing financial reports is to provide useful information for interested parties in making a decision. According to the Indonesian Institute of Accountants in Kasmir (2016) the purpose of financial reports is to "provide information regarding the financial position, performance, and changes in the financial position of a company that is useful for a large number of users in making economic decisions". According to Fahmi (2016) the main purpose of financial reports is "Providing financial information including changes from the elements of financial reports addressed to other parties who have an interest in assessing the financial performance of the company in addition to the company management".

According to Kasmir (2016) the purpose of making or compiling financial reports are:

1. Provide information about the type and amount of assets currently owned by the company.

2. Provide information about the types and amounts of liabilities and capital owned by the company at this time.

3. Provide information about the type and amount of income earned in a certain period.

4. Provide information about the amount of costs and types of costs incurred by the company in a certain period.

5. Provide information about the changes that occur to the company's assets, liabilities and capital.

6. Provide information about the company's management performance in a period.

7. Provide information about the notes to the financial reports.

8. Other financial information.

Characteristics in making financial reporting information very useful for every user of financial reports. Financial reports must be prepared in accordance with generally accepted financial accounting standards and meet the qualitative characteristics of financial reports. There are four main qualitative characteristics of financial reports, namely:

a. Understandable

An important quality contained in financial reports is the ease with which they can be immediately understood by users of financial reports.

b. Relevant

To be useful, information must be relevant to meet the needs of users in the decisionmaking process.

c. Reliability

In order to be useful, information must also be reliable, information has reliable quality if it is free from misleading understanding, material error, and can be relied on to be used as a sincere and honest representation of what it should be presented or which could reasonably be presented.

d. Comparable

Users must be able to compare financial reports between periods to identify trends in financial position and performance. Users must also be able to compare financial reports between institutions to evaluate the relative position of financial reports, performance and changes in financial position. 


\section{Research Methods}

This study is a qualitative method. Through qualitative methods, researchers want to gain in-depth understanding and thoughts about empirical facts that are relevant to the research objectives, of course those relating to the ability of human resources in compiling financial reports at the Secretariat of the Ministry of Religion Office of Sabang City. In line with the above intention, Creswell (2019) stated that qualitative research is "a method for exploring and understanding the meaning that a number of individuals or groups of people consider to be derived from social or humanitarian problems". While Moleong (2016:) suggests that "Qualitative research is based on an effort to build on the views of those who are studied in detail, formed by words, holistic and complex images". Meanwhile, from the point of view of the nature or purpose, this research uses a descriptive method. According to Nawawi (2016) qualitative methods can be interpreted as "problem solving procedures that are investigated by describing / describing the state of the subject / object of research (a person, institution, and also society) at the present time based on the facts that appear or as they are". Through this method the researchers tried to examine the ability of human resources in preparing financial reports at the Regional Office of the Ministry of Religion of Sabang City.

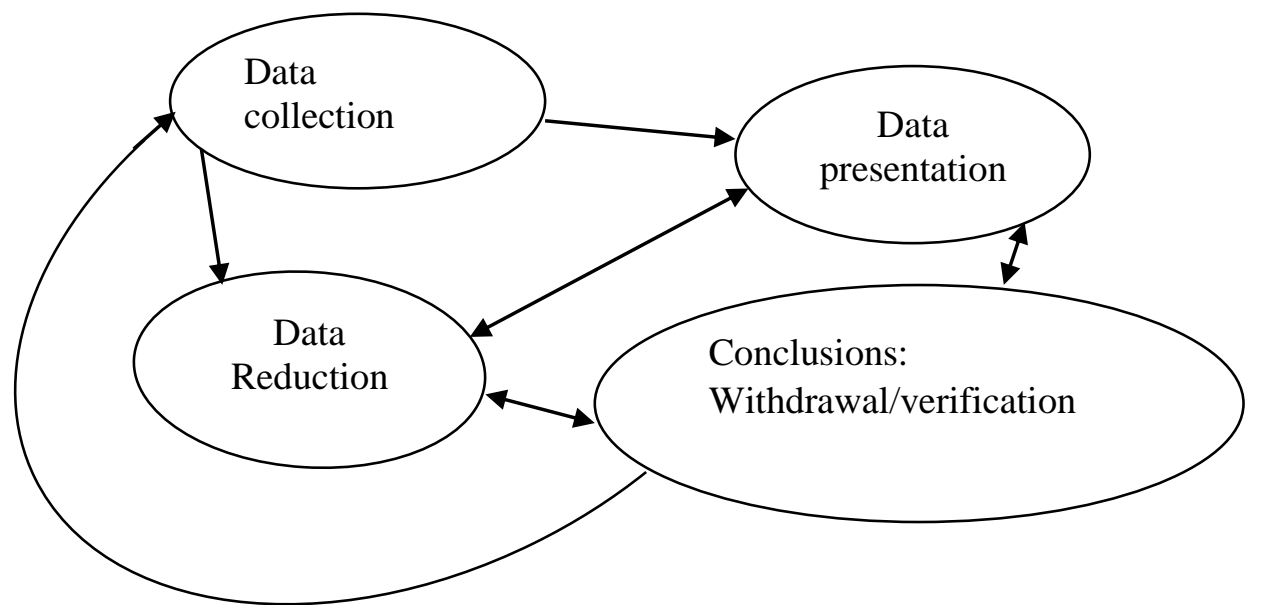

Figure 1. Miles and Huberman's interactive data analysis techniques

\section{Results and Discussion}

The Ministry of Religion Office of Sabang City located at Jalan Agussalim, Sabang 23521 Phone: (0652) 21309 Fax: (0652) 21309. The area of Sabang City includes Weh Island, Klah Island, Rubiah Island, Seulako Island and Rondo Island with an area of 153 $\mathrm{km} 2$, consisting of two Districts and 18 villages. Each of these Districts has the following areas: first, Sukakarya District $73 \mathrm{~km} 2(47.71 \%)$ and second, Sukajaya District $80 \mathrm{~km} 2$ (52.29\%). Sabang City is located on the line 05 $46^{\prime} 28^{\prime \prime N}-05^{\circ} 54^{\prime} 28^{\prime \prime N}$ and $95^{\circ} 13^{\prime} 02^{\prime \prime} \mathrm{E}-$ 95'22'36"E. The forerunner of the Sabang City Department of Religion began in 1963 under the name of Jawatan Agama kewedanaan Sabang, which became the first leader, Tgk. Razali Hasan.

His office stay on Diponegoro Street by occupying a Dutch heritage building borrowed by the Government of Sabang. In 1965 Sabang became a Municipality and the Sabang Mayor's Office was built, so the Ministry of Religion Office changed its address on Diponegoro Street, the former Dutch meeting/entertainment building beside the PDAM 
Sabang Office, now the Head is Tgk. Mahmud Krueng Kalee. In 1967 a representative of the Ministry of Religion of the Municipality of Sabang was appointed, headed by Tgk AR. Hashim. Then in 1968 it was determined that the Ministry of Religion of the Municipality of Sabang was also led by Tgk. AR Hasyim until 1973.

In 1973 the Head of the Ministry of Religion Office of Sabang City led by Drs. Said Salahuddin. Along with the development and expansion of Sabang City in 1984 when the Mayor of Sabang was led by Drs. Yusuf Walad, MBA by carrying out the construction of Sabang on a large scale. Some of the offices were moved to a new location, precisely on Jalan KH. Agussalim Gampong Ie Meulee Sabang, where the Ministry of Religion is now located. With the construction of the first floor building until 2001 but in 2002 it received state budget assistance, a two-story building with adequate space and almost complete supporting facilities was built.

The Ministry of Religion Office of Sabang City is now in charge of two KUA districts, there are Sukajaya and Sukakarya. One Madarash Aliyah, two Madarash Tsanawiyah, three State Ibtidaiyah Madrasah and 2 two Private Ibtidaiyah Madrasas as well as two Raudhatul Athfal Al-qur'ans spread over two sub-districts, namely KUA Sukajaya District which is located at Balohan and KUA Sukakarya is located at Jalan Jend.A .Yani Kel. Upper City of Sabang. Specifically, Madrasah Aliyah Negeri Sabang, MTsN Sabang, and MIN Sabang are located in the Upper City of Sabang, then in 2000 moved to the Gampong Integrated Madrasah Complex, Cot Ba'u Sabang. The location of the Integrated Madrasah land is freed by the Regional Government.

Based on the description and description above, related to the leadership or head of the Sabang City Ministry of Religion office since its inception, namely 1963 until now in 2021, the Sabang City Ministry of Religion Office has been led by as many as 15 heads. For more details regarding the leadership of the Sabang City Ministry of Religion office, it can be seen in table 1 below.

Table 1. The names of the Heads of the Ministry of Religion Office of Sabang City

\begin{tabular}{|l|l|c|}
\hline No & \multicolumn{1}{|c|}{ Name } & From year to year \\
\hline 1 & Tgk. Razali Hasan & $1963-1965$ \\
\hline 2 & Tgk. Mahmud Krueng Kalee & $1965-1968$ \\
\hline 3 & Tgk AR. Hashim & $1968-1973$ \\
\hline 4 & Drs. Said Salahuddin Muhammad & $1973-1985$ \\
\hline 5 & Drs. M. Isa Ibrahim & $1985-1990$ \\
\hline 6 & Drs. H. Zuardi Zain & $1990-1995$ \\
\hline 7 & Drs. H. Zaini Yusuf & $1995-2000$ \\
\hline 8 & Drs. Zainuddun S & $2000-2005$ \\
\hline 9 & Drs. HM Arif Idris & $2005-2008$ \\
\hline 10 & Drs. HM David Pakeh & $2008-2011$ \\
\hline 11 & H. Salman Arifin, S.Pd.I & $2011-2014$ \\
\hline 12 & Drs. H. Taufiq Abdullah & $2014-2014$ \\
\hline 13 & Murhaban, S.Pd.I & $2014-2016$ \\
\hline 14 & Drs. H. Marzuki Basyah & $2016-2020$ \\
\hline 15 & H. Yasin, S. Ag., MA & 2020 to now \\
\hline
\end{tabular}

Source: Ministry of Religion Office of Sabang City, 2021

With regard to the condition of employees at the Ministry of Religion Office of Sabang City by gender, it can be seen in table 2 below. 
Table 2. Number of Civil Servants at the Ministry of Religion of Sabang City by Gender

\begin{tabular}{|c|c|c|c|}
\hline No & Employee gender & Amount & Percentage \\
\hline 1 & Man & 16 & $55 . \%$ \\
\hline 2 & Woman & 13 & $45 . \%$ \\
\hline \multicolumn{2}{|r|}{ Amount } & 29 & $100.00 \%$ \\
\hline
\end{tabular}

Source: Ministry of Religion Office of Sabang City, 2021

The Ministry of Religion Office of Sabang City, apart from having civil servants, also has non-civil servants. Based on available data, in 2021 the Ministry of Religion office of Sabang City will have 25 non-civil servants. For more details regarding the number of non-civil servants at the Ministry of Religion of Sabang City based on gender, it can be seen in table 3 below.

Table 3. Number of Non- Civil Servants Employees at the Ministry of Religion of Sabang City by Gender

\begin{tabular}{|c|c|c|c|}
\hline No & Employee gender & Amount & Percentage \\
\hline 1 & Man & 14 & $56 . \%$ \\
\hline 2 & Woman & 11 & $44 . \%$ \\
\hline & Amount & 25 & $100.00 \%$ \\
\hline
\end{tabular}

Source: Ministry of Religion Office of Sabang City, 2021

Then the number of employees of the Ministry of Religion of Sabang City based on education level can be seen in table 4 below:

Table 4. Number of Civil Servants at the Ministry of Religion of Sabang City Based on Education Level

\begin{tabular}{|c|l|c|c|}
\hline No & Level of education & Amount & Percentage \\
\hline 1 & S2 & 5 & $17 . \%$ \\
\hline 2 & SI & 19 & $66 . \%$ \\
\hline 3 & D3 & 2 & $7 \%$ \\
\hline 4 & High School Equivalent & 3 & $10 \%$ \\
\hline \multicolumn{2}{|c|}{ Amount } & 29 & $100.00 \%$ \\
\hline
\end{tabular}

Source: Ministry of Religion Office of Sabang City, 2021

From the research results show that Civil Servants (ASN) at the Ministry of Religion Office of Sabang City are generally undergraduate graduates, so their ability to prepare financial reports is still very limited. Then in terms of employee placement at the Ministry of Religion Office of Sabang City, apart from education, it is also based on ability, experience, age considerations and the influence of lobbying with superiors. So that education is an important factor in improving human resources at the Ministry of Religion Office of Sabang City, but higher education is not a guarantee for someone to be placed in a structural position by the head.

Then the results of the study also show that to improve the ability to work, the Employees of the Ministry of Religion of Sabang City attend various trainings usually lasting four days. While the results of research related to discipline show that employees at the Ministry of Religion Office of Sabang City enter the office still not on time, and return home not on time based on applicable rules, so that the quality is still not right because there are still many employees who work less disciplined. Thus, the researchers concluded that in general, employees at the Sabang City Ministry of Religion are still not disciplined 
in their work because they enter the office on time, and return home not on time so that the results are not of the right quality but other rules are obeyed and obeyed. Likewise, his presence still has not had an impact on morale due to a lack of initiative and innovation. In general, employees of the Sabang City Ministry of Religion still have a low sense of responsibility, it can be seen from the low level of productivity.

Based on the results of these studies, there are various findings that researchers can describe, including:

Finding 1:

The high level of education of employees of the Ministry of Religion of Sabang City, Finding 2:

there is no guarantee of getting a good placement or promotion.

Employees of the Ministry of Religion of Sabang City have attended various types of training with varying lengths, but this has not had any implications for increasing their ability to prepare financial reports.

Finding 3:

The increase in the discipline of the employees of the Ministry of Religion of Sabang

City has not gone well, especially with regard to quality accuracy and timeliness, but Finding 4: obeys the applicable rules.

Employees of the Ministry of Religion of Sabang City do not yet have a good form of discipline, but have good responsibilities and attitudes.

\section{Conclusion}

Based on the description of the discussion above, the following conclusions can be drawn:

1. State Civil Apparatus (ASN) Ability at the Ministry of Religion Office of Sabang City is still low, especially related to the level of education possessed by the ASN. The highest education is at the Strata I or Bachelor level, but the majors vary so as to improve the ability of ASN in preparing financial reports, it is accompanied by various trainings either held by the Ministry of Religion Office of Sabang City or participating in training held by other institutions. Education is an important factor in improving human resources at the Ministry of Religion Office of Sabang City, but higher education is not a guarantee for someone to be placed in a structural position by the head. Then related to the training attended by the employees of the Ministry of Religion of Sabang City, they participated in various trainings and usually one training lasted for four days. But what's interesting is that even though he has attended various types of training, this has not had any implications for increasing the ability to prepare financial reports.

2. State Civil Apparatus (ASN) Discipline at the Ministry of Religion Office of Sabang City, it is still low, especially regarding entering the office on time, this is often not appropriate, as is the case with the right quality because it is not at the right time so automatically the quality is not right, but the employees obey the applicable rules. This is evidenced by the fact that no employees of the Ministry of Religion of Sabang City have been given sanctions for violating the rules. Likewise, they have a sense of responsibility in accordance with the division of tasks and have a good attitude in carrying out the mandate which is an obligation for employees under the Ministry of Religion Office of Sabang City, so that no employee is indicated to have a bad attitude. 


\section{References}

Achmad, S. Ruky. (2016). Sumber Daya Manusia Berkualitas. Jakarta: PT Gramedia Pustaka Utama.

Agung, Rosidah. (2016). Manajemen Sumber Daya Manusia: Konsep, Teori Dan Pengembangan Dalam Konteks Organisasi Publik. Yogyakarta: Graha Ilmu.

Anwar, Prabu Mangkunegara.(2016). Perencanaan dan Pengembangan Manajemen SumberDaya Manusia. Yogyakarta: PT Refika. Aditama.

Bambang, Swasto. (2017). Manajemen Sumber Daya Manusia. Malang: Universitas Brawijaya Press.

Creswell, John. W. (2019). Research Design. Diterjemahkan oleh. Fawaid, Achmad. Yogyakarta: Pustaka Pelajar.

Daryanto. (2016). Sosiologi Organisasi Suatu Pengantar. Jakarta: PT Raja Grafindo Persada.

Dewi, Hanggraeni. (2016). Manajemen Sumber daya Manusia. Jakarta: Lembaga Penelitian Fakultas Ekonomi Universitas Indonesia.

Edy, Sutrisno.(2016). Manajemen Sumber Daya Manusia. Jakarta: Kencana.

Fahmi. (2016). Prinsip-prinsip dan Etika Organisasi. Yogyakarta: Gajah Mada University Press.

Hasibuan, Malayu. (2016). Manajemen Sumber Daya Manusia. Edisi Revisi. Jakarta: Bumi Aksara.

Huberman, Matthew B. Miles A. Michael. (2007). Analisis Data Kualitatif. Jakarta: Universitas Indonesia.

Jones, J. J., dan Walters D. L. (2016). Human Resourse Management in Education (Manajemen HUMAN RESOURCES (HR) dalam Pendidikan). Yogyakarta: QMedia.

Kasmir. (2016). Manajemen Perbankan. Jakarta: PT Raja Grafindo Persada.

Kasmir. (2016). Sistem Administrasi Pemerintahan Daerah. Jakarta: Bumi Aksara.

Moloeng, Lexy. J. (2016). Metode Penelitian Kualitatif. Bandung: Remaja Rosdakarya.

Mulyana, Dedy. (2016). Metodologi Penelitian Kualitatif Paradigma Baru Ilmu Komunikasi Dan Ilmu Sosial Lainnya. Bandung: Remaja Rosdakarya.

Nawawi. (2016). Manajemen Peningkatan Sumber Daya Manusia. Jakarta: PT Salemba Emban Patria.

Niati, D. R., Siregar, Z. M. E., \& Prayoga, Y. (2021). The Effect of Training on Work Performance and Career Development: The Role of Motivation as Intervening Variable. Budapest International Research and Critics Institute (BIRCI-Journal): Humanities and Social Sciences, 4(2), 2385-2393. https://doi.org/10.33258/birci.v4i2.1940

Philip, Kotler. (2018). Manajemen Pemasaran di Indonesia:Analisis, Perencanaan, Implementasi dan Pengendalian. Jakarta: Salemba Empat.

Shah, M. M., et al. (2020). The Development Impact of PT. Medco E \& P Malaka on Economic Aspects in East Aceh Regency. Budapest International Research and Critics Institute-Journal (BIRCI-Journal) Volume 3, No 1, Page: 276-286.

Susilo, Martoyo. (2018). Manajemen Sumber Daya Manusia. Yogyakarta: BPFE.

Thoha, Miftah. (2016). Birokrasi Pemeritahan Indonesi di Era Reformasi. Yogyakarta: Media Widya Mandala.

Torang, Syamsir. (2015). Organisasi dan Manajemen (Perilaku, Struktur, Budaya dan Perubahan Organisasi). Bandung: Alfabeta. 
Werdhiastutie, A. et al. (2020). Achievement Motivation as Antecedents of Quality Improvement of Organizational Human Resources. Budapest International Research and Critics Institute-Journal (BIRCI-Journal) Volume 3, No 2, Page: 747-752.

Winardi. (2016). Teori Organisasi dan Pengorganisasian. Jakarta: PT. Rajagrafindo Persada. 